\title{
Cisplatin-Induced Apoptosis in Rat Dorsal Root Ganglion Neurons Is Associated with Attempted Entry into the Cell Cycle
}

\author{
Jagjit S. Gill and Anthony J. Windebank \\ Molecular Neuroscience Program, Mayo Clinic and Mayo Foundation, Rochester, Minnesota 55905
}

\begin{abstract}
Platinum compounds induce apoptosis in malignant cells and are used extensively in the treatment of cancer. Total dose is limited by development of a sensory neuropathy. We now demonstrate that when rats are administered cisplatin $(2 \mathrm{mg} / \mathrm{kg}$ i.p. for $5 \mathrm{~d})$, primary sensory neurons in the dorsal root ganglion die by apoptosis. This was reproduced by exposure of dorsal root ganglion neurons and PC12 cells to cisplatin $(3 \mu \mathrm{g} / \mathrm{ml})$ in vitro. Apoptosis was confirmed by electron microscopy, DNA laddering, and inhibition by the caspase inhibitor z-VAD.fmk $(100 \mu \mathrm{M})$. Cell death in vitro was preceded by upregulation of cyclin D1, cdk4, and increased phosphorylation of retinoblastoma protein; all are indicators of cell cycle advancement. The level of p16 ${ }^{\mathrm{INK} 4 \mathrm{a}}$, an endogenous inhibitor of the cyclin D1/cdk4 complex decreased. Exposure of PC12 cells and dorsal root ganglion neurons to increased levels of nerve growth factor $(100 \mathrm{ng} /$ $\mathrm{ml}$ ) prevented both apoptosis and upregulation of the cell cycle markers. Cancer cells without nerve growth factor receptors ( $\left.\mathrm{gp}^{140 \mathrm{TrkA}}\right)$ were not protected by the neurotrophin. This indicated that cisplatin may kill cancer cells and neurons by a similar mechanism. In postmitotic neurons, this involves an attempt to re-enter the cell cycle resulting in apoptosis which is specifically prevented by nerve growth factor. (J. Clin. Invest. 1998. 101:2842-2850.) Key words: chemotherapy $\bullet$ platinum neurotoxicity $\bullet$ neurotrophins $\bullet$ nerve growth factor
\end{abstract}

\section{Introduction}

cis-dichlorodiamine platinum (CDDP,${ }^{1}$ cisplatin) is the drug of choice for treatment of germ cell cancers $(1,2)$. It is also used adjunctively for other solid tumors but the total dose that can be administered is limited by serious adverse effects including renal toxicity and peripheral neurotoxicity $(1,3)$. The incidence of nephropathy, which was dose limiting, has been significantly reduced by chloride diuresis. Maintenance of high

Address correspondence to Jagjit S. Gill, Mayo Clinic and Mayo Foundation, Molecular Neuroscience Program, 1501 Guggenheim Building, 200 First Street SW, Rochester, MN 55905. Phone: 507-2841781; FAX: 507-284-3383; E-mail: gill.jagjit@mayo.edu

Received for publication 8 July 1997 and accepted in revised form 13 April 1998.

1. Abbreviations used in this paper: $\mathrm{CDDP}$, cis-dichlorodiamine platinum; cdk, cyclin-dependent protein kinase; DRG, dorsal root ganglion; ECL, enhanced chemiluminescence; NGF, nerve growth factor; $\mathrm{PC} 12$, pheochromocytoma cell line; $\mathrm{pRb}$, retinoblastoma protein.

The Journal of Clinical Investigation

Volume 101, Number 12, June 1998, 2842-2850

http://www.jci.org chloride concentrations in kidney cells prevents aquation and activation of cisplatin (4). Peripheral neuropathy was first reported soon after the drug was introduced $(1,3)$. The neuropathy is dose limiting and closely related to total cumulative drug dose (5-8). Significant peripheral neurotoxicity is apparent in the majority of adult patients who receive $>400-500 \mathrm{mg} / \mathrm{m}^{2}$ of cisplatin $(3,9,10)$. The neuropathy is predominantly sensory with initial complaints of paresthesiae in the distal extremities (10). This may progress to severe sensory ataxia. Neuropathological studies have shown loss of large myelinated fibers and evidence of axonal degeneration $(10,11)$. The neuropathy may continue to progress for several months after cessation of cisplatin (12) and symptoms may develop 3-8 wk after the last dose of chemotherapy (13). Other platinum compounds in active or experimental clinical use, including carboplatin and oxaliplatin, are also associated with sensory neurotoxicity to varying degrees (14-16).

The reason for predominant sensory neuron toxicity may relate to drug access rather than selective neuronal vulnerability. Cisplatin does not cross the blood-brain barrier and, therefore, motor neurons and other central nervous system neurons are not directly exposed to toxic levels of drug. The dorsal root ganglion (DRG) is supplied by fenestrated capillaries. Consequently, sensory neurons are exposed to serum levels of drug. This has been confirmed in human autopsy studies. Tissue platinum assays revealed the highest platinum concentration in tumor tissue (mean $3.3 \mu \mathrm{g} / \mathrm{gram}$ ), but similarly high concentrations were found in peripheral nervous tissue $(3.5 \mu \mathrm{g} / \mathrm{gram}$ in sciatic nerve and $3.8 \mu \mathrm{g} / \mathrm{gram}$ in spinal ganglia). This compared with much lower concentrations in brain $(0.17 \mu \mathrm{g} / \mathrm{gram})(5$, 10). Electrophysiological studies in cancer patients treated with cisplatin confirm that large diameter sensory axons are involved $(17,18)$. Most studies have been interpreted as suggesting that the DRG neuron is the primary target (6).

Development of animal models for the study of cisplatin neurotoxicity has been difficult because of the development of severe nephrotoxicity before neurotoxicity. In surviving animals, the possibility that neuropathy is due to renal failure rather than to cisplatin has been difficult to elucidate. Careful attention to hydration and dose schedule has reduced these difficulties. In most cases $1-2 \mathrm{mg} / \mathrm{kg}$ of cisplatin once or twice each week have been used. Animals have then been followed for 3-10 wk. None of the animal studies have demonstrated an obvious clinical deficit although behavioral studies in cisplatintreated mice have indicated a deficit in balance function (19). This was associated with biochemical abnormalities in DRG and slowing of tail nerve conduction. Several other groups have demonstrated similar slowing of nerve conduction in rats (20-24). Using similar doses, microscopic changes in DRG neurons including neuronal shrinkage and nucleolar abnormalities have been identified (19, 24-27).

Mechanistic studies of cisplatin-induced neurotoxicity have been limited. We and others have demonstrated that cisplatin inhibits neurite outgrowth from neurons in vitro (28-30). Vesicular axonal transport and microtubule assembly are altered 
by cisplatin $(31,32)$. GAP-43 mRNA expression is upregulated and various neuropeptides are downregulated in DRG exposed to cisplatin in vivo. Whether any of these changes are of primary importance in neurotoxicity is unknown.

Several agents have been shown to have a protective effect against cisplatin neurotoxicity in vitro and in animal models. These include reduced glutathione $(20,21,33,34)$, other thiols $(35,36)$, the ACTH like peptides $(22,37,38)$, and neurotrophic agents $(19,28,29,39-43)$. None of these have yet progressed to effective human treatment and in most cases, the rationale for use is empiric. Work presented in this study describes a neuroprotective effect conferred by nerve growth factor (NGF) on cisplatin-treated sensory neurons. It is proposed that cisplatin-induced cell death involves re-entry of these postmitotic neurons into the cell cycle which is prevented by NGF.

\section{Methods}

Tissue culture. Dorsal root ganglia were removed by microdissection from 15-d-old Sprague Dawley rats (Harlan Sprague Dawley, Madison, WI) and dissociated with $0.25 \%$ trypsin for $30 \mathrm{~min}$. Dissociated cells were plated on ACLAR (American Chemical, Pleasant Gap, PA) dishes coated with ammoniated and air-dried, rat tail collagen and incubated in EMEM supplemented with $5.0 \mathrm{ng} / \mathrm{ml}$ of $2.5 \mathrm{~S}$ mouse submaxillary gland NGF (Bioproducts for Science, Indianapolis, IN), $15 \%$ calf bovine serum (Hy-Clone Laboratories, Logan, UT) $0.6 \%$ glucose, $50 \mu \mathrm{g} / \mathrm{ml}$ ascorbic acid, and $1.4 \mathrm{mmol} \mathrm{L}$-glutamine. Enriched neuronal cultures were obtained by treatment with $10^{-5} \mathrm{M}$ fluorodeoxyuridine (Sigma Chemical Co., St. Louis, MO) for $4 \mathrm{~d}$. All cultures were incubated at $37^{\circ} \mathrm{C}$ in $5 \% \mathrm{CO}_{2}$. Where stated, cultures were treated with $3.5 \mu \mathrm{g} / \mathrm{ml}$ cisplatin (Sigma Chemical Co.) and varying concentrations of NGF $(50-100 \mathrm{ng} / \mathrm{ml})$. Caspase inhibition was achieved by exposing cultures to the irreversible caspase inhibitor z-VAD.fmk (100 $\mu \mathrm{M}$; Bachem, Torrance, CA).

Grid counting was used for quantitation of DRG neurons. ACLAR dishes with a 0.5 -mm grid pattern (44) were made in the laboratory for counting neuron-enriched DRG cultures. In this protocol, the same cells can be counted sequentially allowing high reproducibility ( $>97.0 \%$ interobserver reliability) with low numbers of cells $(<200$ cells per condition). Four to six replicate cultures were used for each condition. Cell counts were always completed by a blinded observer to eliminate bias.

The rat pheochromocytoma cell line (PC12) was originally a gift from the laboratory of Dr. Eric M. Shooter (Stanford University, Palo Alto, CA). The human colon (HT-29) and breast (MCF-7) cancer cell lines were a gift from Dr. Matthew M. Ames (Mayo Comprehensive Cancer Center, Rochester, MN).

Animals. Male Harlan-Sprague Dawley rats (450 grams) were injected intraperitoneally with $2 \mathrm{mg} / \mathrm{kg}$ cisplatin every day for $5 \mathrm{~d}$, followed by a 5-d recovery period. Animals were killed and L5 DRG removed and prepared for electron microscopy as described below. Cisplatin-treated rats were fed ad libitum. Pair-fed, weight-matched control rats were injected with saline vehicle every day for $5 \mathrm{~d}$ and allowed to recover for an additional $5 \mathrm{~d}$.

Electron microscopy. DRG cultures and DRG removed from rats were fixed for a minimum of $4 \mathrm{~h}$ with Trump's fixative followed by $1 \mathrm{~h}$ postfixation in $1 \% \mathrm{OsO}_{4}$. Cultures were stained en bloc with $2 \%$ uranyl acetate, dehydrated, and embedded in Spurr's resin. Sections $(0.8 \mu \mathrm{m})$ were stained with lead citrate and examined with a Philips CM10 transmission electron microscope.

DNA fragmentation. DNA from enriched DRG neuronal cultures was isolated by modification of a previous method (45). DRG neuronal cultures and cancer cell lines were exposed to cisplatin (3.5 $\mu \mathrm{g} / \mathrm{ml}$ ) for $12-48 \mathrm{~h}$. After treatment, cells were washed in PBS and pelleted. Cells were lysed in $200 \mu \mathrm{l}$ of $50 \mathrm{mM}$ Tris- $\mathrm{HCl} \mathrm{pH} \mathrm{9.0,20} \mathrm{mM}$ EDTA, $10 \mathrm{mM} \mathrm{NaCl}, 1.1 \%$ sodium dodecyl sulfate (wt/vol), and 10 $\mathrm{mg} / \mathrm{ml}$ Proteinase K (Gibco/BRL, Rockville, MD). Cells were incubated in lysis buffer for $48 \mathrm{~h}$ at $48^{\circ} \mathrm{C}$. Samples were cooled at room temperature for $15 \mathrm{~min}$ and sedimented. $200 \mu \mathrm{l}$ of phenol-chloroform was added to each pellet, vortexed, and sedimented again. After a second phenol-chloroform extraction, an aliquot containing $5 \mu \mathrm{g}$ DNA was added to $50 \mu \mathrm{g} / \mu \mathrm{l}$ RNase A in $3 \mu \mathrm{l}$ gel loading buffer and incubated at room temperature for $1 \mathrm{~h}$. Samples were electrophoresed in $1.2 \%$ agarose gel and visualized with ethidium bromide. Neutralizing antibodies to the p75 receptor, REX (46) was a generous gift from Dr. Louis Reichardt (University of California, San Francisco).

Western blotting. Immunoblotting of cell cycle related proteins was performed to characterize the expression of these elements in cisplatin-treated DRG neuronal cultures and cancer cell lines. Lysates were obtained and separated by SDS-PAGE (5-8\%) and electrophoretically transferred to nitrocellulose membranes as described previously (47). Membranes were put in a $4.0 \%$ BSA solution (in PBS) overnight at $4^{\circ} \mathrm{C}$ to block nonspecific protein binding, immunoblotted with $0.5-1.0 \mu \mathrm{g} / \mathrm{ml}$ primary antibody to the defined cell cycle proteins (cyclin D1, cdk4, p16 ${ }^{\mathrm{INK} 4 \mathrm{a}}$, and retinoblastoma protein (pRb); Transduction Laboratories, Lexington, $\mathrm{KY}$ ) for $1 \mathrm{~h}$ at room temperature followed by blotting with anti-mouse HRP-conjugated secondary antibody (1:10,000; Amersham Corp., Arlington Heights, IL) for an additional hour. Western blot analysis was also performed using a monoclonal antibody to the CPP32 protein $(1: 1,000$; Transduction Laboratories). Membrane washes in PBS plus $0.05 \%$ Tween20 were performed after both primary and secondary antibody incubations. Enhanced chemiluminescence (ECL; Amersham Corp.) was used to visualize immunoblotted proteins.

Caspase activity assay. Assay for CPP32-like activity was performed as described previously (48). Aliquots of cytosolic extracts (40 $\mu \mathrm{g}$ of protein in $500 \mu \mathrm{l}$ extraction buffer) were mixed with equal volume of $40 \mu \mathrm{M}$ fluorescent tetrapeptide substrate (Ac-DEVD-AMC; Bachem) in the same buffer solution. Free aminomethylcoumarin (AMC) accumulation, which resulted from cleavage of the aspartateAMC bond, was monitored after $30 \mathrm{~min}$ at $37^{\circ} \mathrm{C}$ using a FS900 fluorometer (Edinburgh Instruments Ltd., Edinburgh, United Kingdom) at 360-nm excitation and 460-nm emission wavelengths. Data were expressed as a percentage of caspase activity in samples from untreated cultures.

Immunofluorescent microscopy. Immunocytochemistry was used to confirm that the increased expression of cyclin D1 detected by Western blot analysis was in neurons. We also determined if these changes in cellular protein levels preceded apoptotic cell death demonstrated by bis-benzimide staining. Cisplatin-treated DRG cultures were fixed in $4.0 \%$ paraformaldehyde for $10 \mathrm{~min}$ at room temperature, washed in PBS and nonspecific protein binding blocked by incubation in $4.0 \%$ BSA for $1 \mathrm{~h}$. After permeabilizing with $1 \mu \mathrm{g} / \mathrm{ml}$ proteinase $\mathrm{K}$ in $\mathrm{PBS}$ for $15 \mathrm{~min}$ at $37^{\circ} \mathrm{C}$, anticyclin $\mathrm{D} 1$ monoclonal antibody $(2.0 \mu \mathrm{g} / \mathrm{ml}$; Transduction Laboratories) was added for $4 \mathrm{~h}$. This was the same antibody as used for Western blotting. After rinsing, anti-mouse IgG-FITC conjugated secondary antibody (1:1,000; Sigma Chemical Co.) was added for $2 \mathrm{~h}$. Cultures were viewed and images recorded using a fluorescence microscope (Axiophot; Carl Zeiss, Thornwood, NY) with fluorescein optics.

\section{Results}

Cisplatin-induced apoptosis in dorsal root ganglion neurons. In the first series of experiments, we examined the mode of cell death induced by cisplatin. Two model systems were used; embryonic day 15 rat DRG neurons in culture and adult rats treated with intraperitoneal cisplatin. In both cases, neurons were postmitotic. When DRG neurons were exposed in vitro to therapeutic concentrations of cisplatin $(3.5 \mu \mathrm{g} / \mathrm{ml})$ and examined by electron microscopy after $48 \mathrm{~h}$, characteristic morphologic changes of apoptosis were observed. These included 
A
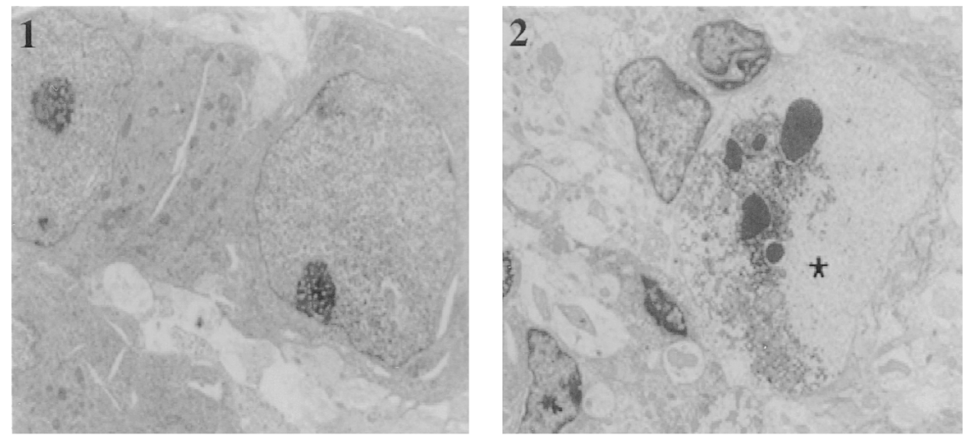

C

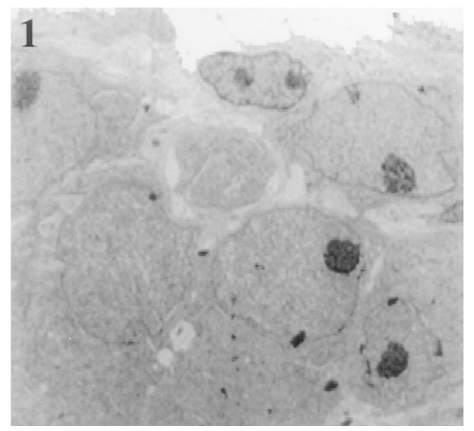

B

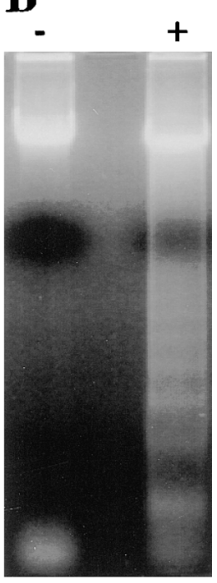

Figure 1. Cisplatin induces apoptosis in DRG neurons. (A) DRG cultures were treated with cisplatin (3.5 $\mu \mathrm{g} / \mathrm{ml}$ ) for $48 \mathrm{~h}$ and then observed by electron microscopy. Characteristic changes of apoptotic cell death (*) including nuclear fragmentation and condensed cytoplasm in the presence of an intact plasma membrane were observed (2). These changes were not seen in untreated cultures $(1$; magnification of 2,800$)$. (B) Internucleosomal fragmentation by gel electrophoresis, characteristic of apoptotic cell death, was also observed in neuron-enriched DRG cultures exposed to cisplatin as described above. DNA ladders were observed in cisplatin treated cultures $(+)$ but not in untreated cultures $(-) .(C)$ DRG neurons from rats treated with $2 \mathrm{mg} / \mathrm{kg}$ cisplatin (i.p.) daily for $5 \mathrm{~d}$ followed by $5 \mathrm{~d}$ without treatment revealed morphological changes consistent with apoptotic cell death (arrow; 2).

These neurons undergoing apoptosis resembled those from the in vitro studies. Apoptotic changes were not seen in DRG from control rats injected with saline vehicle $(1$; magnification of 2,100).

cell shrinkage, nuclear condensation and fragmentation with maintenance of plasma membrane and intracellular organelle integrity (Fig. $1 A$ ). Additional evidence for the occurrence of apoptosis was obtained by isolating DNA from cisplatintreated DRG neurons and subsequent electrophoretic separation (Fig. $1 \mathrm{~B}$ ). DNA laddering, indicative of internucleosomal fragmentation, was observed in cisplatin-treated cultures at the same time as the apoptotic changes were seen by electron microscopy. When rats were treated with cisplatin $(2 \mathrm{mg} / \mathrm{kg}$ i.p. for $5 \mathrm{~d}$ ) and killed after $10 \mathrm{~d}$, similar morphological changes were observed (Fig. $1 C$ ). This schedule is similar to that used for treating humans.

Activation of the mammalian interleukin- $1 \beta$ converting enzyme-like cysteine proteases (caspases) is one of the final steps in apoptotic cell death. Inhibition of caspase activation may, therefore, protect cells from dying by this pathway. Addition of the irreversible caspase inhibitor z-VAD.fmk to cisplatin$(3.5 \mu \mathrm{g} / \mathrm{ml}$ for $48 \mathrm{~h})$ treated cultures reduced the degree of DNA laddering compared with cultures exposed to cisplatin alone (Fig. $2 \mathrm{~A}$ ). This reduction in internucleosomal fragmentation was accompanied by increased neuron viability (Fig. 2 $B$ ). Caspase activation was confirmed by demonstrating cleavage of CPP32/caspase-3 (Fig. 2 C), the enzyme responsible for the specific proteolytic breakdown of poly(ADP-ribose) polymerase/PARP that occurs at the onset of apoptosis (48). Cleavage of CPP32 was not observed in cisplatin-treated cultures exposed to the caspase inhibitor z-VAD.fmk. To examine if the effect on neuronal survival mediated by caspase inhibition related to decreased caspase activity, we quantitated changes in enzyme activity in neuronal cultures. CPP32-like (caspase-3) protease activity was assayed using the specific fluorogenic tetrapeptide substrate Ac-DEVD-aminomethylcoumarin(AMC). Cisplatin-treated $(3.5 \mu \mathrm{g} / \mathrm{ml}$ for $48 \mathrm{~h})$ cultures revealed a significant elevation of CPP32-like activity in cytosolic extracts rising to $182 \pm 6.4 \%$ increase of control (Fig. $2 \mathrm{D}$ ). This fluorometric assay did not detect significant changes in CPP32-like activity in extracts from cultures exposed to cisplatin plus $100 \mu \mathrm{M} z-V A D$.fmk for $48 \mathrm{~h}$.

Collectively, these experiments demonstrated that cisplatin-induced apoptosis of DRG neurons in vitro and in vivo at concentrations or doses associated with the onset of peripheral neuropathy in cancer patients. We also confirmed previous observations that cisplatin induced apoptosis in human colon (HT-29) and breast (MCF-7) cancer cell lines (Fig. 3). Biochemically, cisplatin induced apoptosis activated the caspase cascade, an event which was blocked by the inhibitor z-VAD.fmk.

Cisplatin upregulated markers of cell cycle advancement. Western blot analysis of proteins from neuron-enriched DRG cultures exposed to cisplatin $(3.5 \mu \mathrm{g} / \mathrm{ml}$ for 12 and $24 \mathrm{~h})$ demonstrated increased expression of cyclin D1, a marker of progression through $\mathrm{G} 1$ phase of the cell cycle (Fig. $4 A$ ). The level of protein expression in differentiated, untreated cultures was low. Exposure to cisplatin resulted in a significant increase in cyclin D1 within $12 \mathrm{~h}$ of treatment. In cisplatin-treated cultures exposed to the caspase inhibitor z-VAD.fmk, cyclin D1 protein expression was not reduced as compared to cultures exposed to cisplatin alone. This demonstrated that upregulation of cyclin D1 expression was occurring upstream of caspase 
A

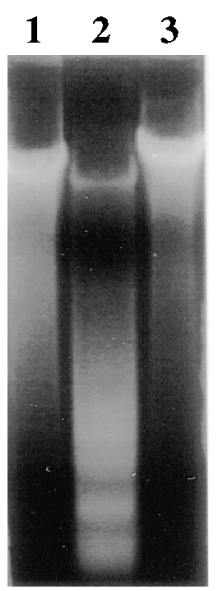

C

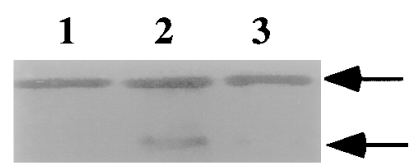

B

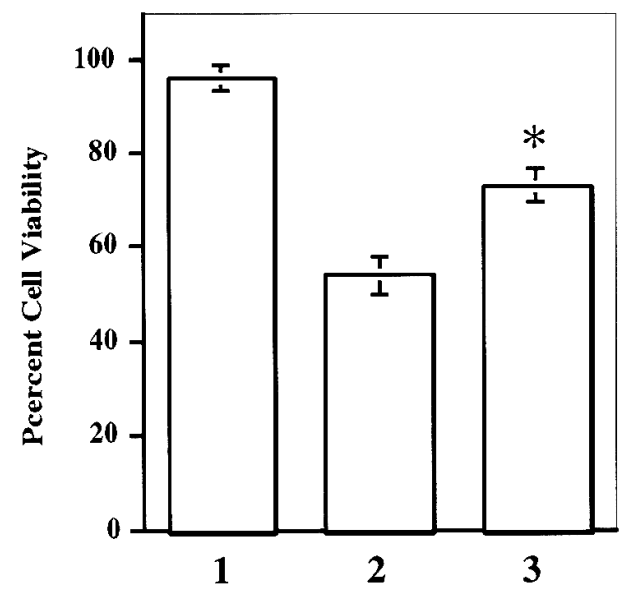

D

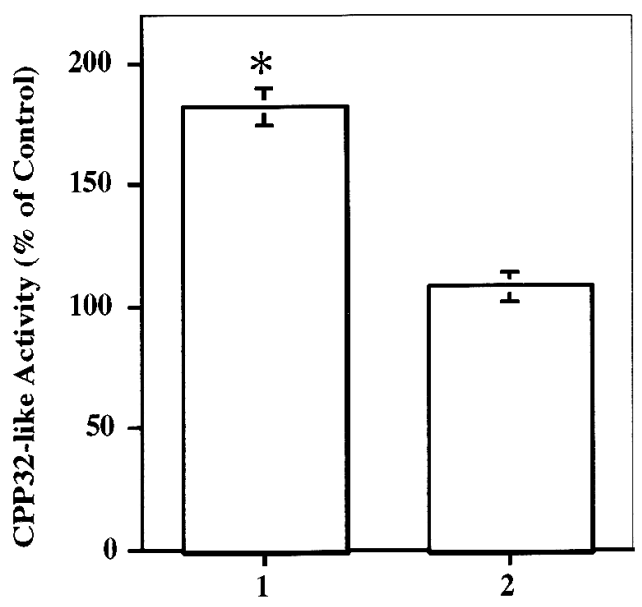

Figure 2. Effect of caspase inhibition on cisplatin induced apoptosis in DRG neurons. (A) DRG cultures were exposed to $3.5 \mu \mathrm{g} / \mathrm{ml}$ cisplatin with or without the addition of the caspase inhibitor $\mathrm{z}$-VAD.fmk $(100 \mu \mathrm{M})$ for $48 \mathrm{~h}$; untreated control cultures in lane 1 . DNA was harvested, separated by gel electrophoresis, and visualized by ethidium bromide. Internucleosomal fragmentation (DNA ladders) was reduced in cultures treated with cisplatin and z-VAD.fmk (lane 3) compared with cultures treated with cisplatin alone (lane 2). Control neurons (lane 1) had intact genomic DNA. All cultures were incubated in the presence of $5 \mathrm{ng} / \mathrm{ml} \mathrm{NGF}$. (B) Neuron survival was studied using phase contrast microscopy and grid counting. The number of viable neurons after $48 \mathrm{~h}$ of cisplatin (CDDP; $3.5 \mu \mathrm{g}$ / $\mathrm{ml})$ treatment was significantly increased $\left({ }^{*} P<0.01\right.$ Student's $t$ test) in the presence of z-VAD.fmk (3) compared to neurons exposed to cisplatin alone (2). Cell viability was also determined in untreated neurons $(1)$. (C) Western blot analysis of neuronal cultures revealed the cleavage of CPP32 (caspase-3) in cultures exposed to $3.5 \mu \mathrm{g} / \mathrm{ml}$ cisplatin (lane 2). Cleavage of CPP32 was reduced in cisplatin cultures treated with $100 \mu \mathrm{M}$ of the caspase inhibitor z-VAD.fmk (lane 3). Protein lysates from untreated cultures were separated in lane 1. Upper arrow represents intact $\mathrm{CPP} 32$ protein and lower arrow reflects the cleaved $17-\mathrm{kD}$ activated fragment. $(D)$ CPP32-like caspase activity in cytosolic protein extracts from neuron-enriched DRG cultures was determined. Cells were exposed to $3.5 \mu \mathrm{g} / \mathrm{ml}$ cisplatin alone (1) or with $100 \mu \mathrm{M}$ $\mathrm{z}-\mathrm{VAD}$.fmk (2) for $48 \mathrm{~h}$. Cleavage of AcDEVD-AMC was assayed fluorometrically by measuring the accumulation of free aminomethylcoumarin. Cisplatin-treated cultures $(1)$ revealed a $182 \pm 6.4 \%$ increase of control of CPP32-like activity which was re-

duced to a $108 \pm 7.9 \%$ increase in the presence of the caspase inhibitor z-VAD.fmk (2). Cisplatin treatment alone demonstrated a significant increase $(* P<0.001$ Student's $t$ test) as compared to untreated cultures. Protease activity is expressed as percent increase of untreated cultures $\pm \operatorname{SEM}(n=4)$.

activation, suggesting that entry into $\mathrm{G} 1$ phase of the cell cycle preceded the initiation of apoptosis. Cyclin D1 protein levels were only reduced in cisplatin-treated neurons cultured in the presence of high concentrations of the differentiating growth factor NGF (Fig. $4 A$ ). It was confirmed by immunocytochemistry that this upregulation was occurring primarily in neurons (Fig. $4 B$ ). This suggested that cisplatin induced DRG neurons to enter the cell cycle before any detectable morphological measure of cell death $(48 \mathrm{~h})$ was observed. Cisplatin-induced cell cycle perturbation was further studied by examining the phosphorylation state of pRb (Fig. $4 C$ ). These studies were performed at $12 \mathrm{~h}$ cisplatin treatment which is $36 \mathrm{~h}$ before any observation of drug-induced cell death by the criteria of DNA laddering or morphological changes characteristic of apoptosis. Advancement through the cell cycle is accompanied by hyperphosphorylation of $\mathrm{pRb}$; return to early $\mathrm{G} 1$ results in hy- pophosphorylation. Cisplatin-treated neurons revealed hyperphosphorylation of $\mathrm{pRb}$ which was not reduced upon exposure to the caspase inhibitor z-VAD.fmk. These findings support the observation described above of cell cycle entry (i.e., cyclin D1 expression) preceding caspase activation in cisplatintreated neurons.

Advancement through the cell cycle from G0 through G1 is accompanied by upregulation of cyclin D1 and decreased expression of the endogenous cyclin D1 inhibitor, p16 ${ }^{\mathrm{INK} 4 \mathrm{a}}$. Increasing the concentration of NGF in cisplatin-treated cultures resulted in increased expression of p16 ${ }^{\mathrm{INK} 4 \mathrm{a}}$ by $6 \mathrm{~h}$. This suggested that the neurotrophin was maintaining neurons in the quiescent stage of the cell cycle. Similar findings were produced by addition of olomoucine, a nonspecific cyclin-cdk inhibitor, to PC12 cells. This resulted in reduced cyclin D1-cdk4 complex formation. Immunoprecipitation with antibodies to 

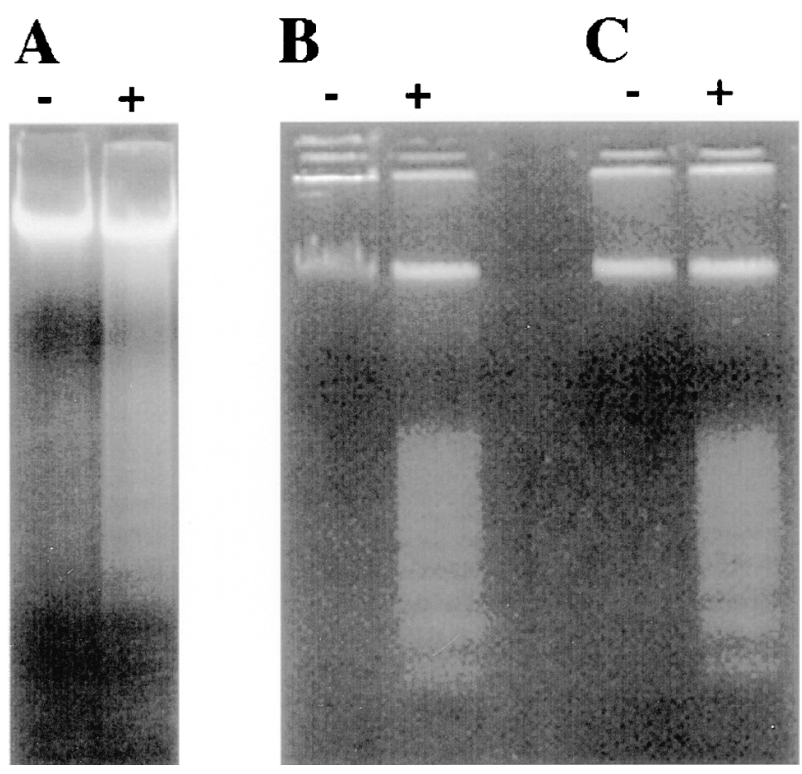

Figure 3. Cisplatin induces apoptosis in the neuron-like cell line PC12 and in cancer cells. The rat PC12 $(A)$, human colon/HT-29 $(B)$, and breast/MCF-7 $(C)$ cell lines were exposed to $3.5 \mu \mathrm{g} / \mathrm{ml}$ cisplatin $(+)$. DNA was harvested and separated by gel electrophoresis and visualized by ethidium bromide. DNA laddering was observed after $24 \mathrm{~h}$ exposure to cisplatin in treated $(+)$ but not in untreated $(-)$ cells.

cyclin D1 followed by detection with antibodies to cdk4 demonstrated decreased expression of cyclin D1-cdk4 complexes (data not shown).

Nerve growth factor prevented cisplatin-induced apoptosis in DRG neurons and PC12 cells but not colon cancer cells. NGF has been shown in some animal models (19) and in tissue culture $(29,49)$ to protect against some aspects of cisplatin neurotoxicity. In these studies, behavioral measures or surrogates of DRG function, such as neurotransmitter peptide content or neurite outgrowth, were studied. Positive effects of NGF were not found in all studies using these models (30). Having established a model of apoptotic neuronal death, we wished to explore the potential protective role of neurotrophic support. NGF was used, rather than another neurotrophin, because the cellular mechanism of action has been well characterized in neurons. PC12 cells have been used extensively to study the mechanism of NGF action. This cell line is not NGF dependent for survival. When exposed to NGF, it stops dividing and differentiates into a neuron-like cell. It expresses both high (gp140 $\left.{ }^{\text {TrkA }}\right)$ and low (p75) affinity NGF receptors but not other neurotrophin receptors.

Addition of supra-physiological levels of NGF (50-100 $\mathrm{ng} / \mathrm{ml}$ ) increased viability in DRG cultures exposed to cisplatin for $48 \mathrm{~h}$ (Fig. $5 \mathrm{~A}$ ). Increased cell viability with NGF treatment correlated with a reduction in DNA fragmentation (Fig. $5 B$ ). Identical neuroprotection was observed in differentiated PC12 cells (Fig. $6 \mathrm{~A}$ ). Selective inhibition of the gp140 ${ }^{\mathrm{TrkA}}$ receptor tyrosine kinase by addition of K252a blocked this protective effect (Fig. 6 D). NGF-mediated neuroprotection was observed in cisplatin-treated cells cultured in the presence of the p75 NGF receptor neutralizing antibody REX (data not shown). These findings would suggest that the neuroprotective effect of NGF in cisplatin-induced neuronal injury acts through the gp $140^{\text {TrkA }}$ receptor and initiation of down stream signal cascade elements involved in cell survival or differentiation. The rationale for NGF therapy is that it will promote survival of neurons but not cancer cells in patients treated with cisplatin. Expression of the gp140 ${ }^{\text {TrkA }}$ receptor is confined to neurons; it is rarely expressed in cancer cells. NGF did not protect HT-29 cells from cisplatin-induced apoptosis demonstrated by DNA laddering (Fig. $6 \mathrm{~B}$ ). This human colon cancer cell did not express gp140 TrkA (Fig. 6 C).

\section{Discussion}

We are trying to understand the mechanisms by which chemotherapeutic agents cause damage to the nervous system. Why do drugs, designed to kill rapidly dividing cancer cells, injure nonproliferative, differentiated neurons. We have shown for the first time that cisplatin caused apoptotic cell death in primary sensory neurons in vitro and in vivo. Apoptosis in these neurons was preceded by alterations in cell cycle regulatory proteins suggesting that these terminally differentiated neurons were attempting to enter the cell cycle. While cisplatininduced apoptosis was reduced in cultures exposed to the caspase inhibitor z-VAD.fmk, expression of proteins indicative of cell cycle entry and progression were not affected by this inhibitor. Increasing the concentration of NGF appeared to stabilize the cells in the quiescent or G0 stage of the cell cycle, which is the normal differentiated state. NGF also prevented apoptosis in both sensory neurons and NGF-responsive PC12 cells, but not in cancer cells without high affinity NGF receptors.

Although the mechanism of antineoplastic activity is uncertain, cisplatin appears to exert its biological effect by binding directly to DNA. Cisplatin forms DNA intrastrand adducts at $\mathrm{d}(\mathrm{GpG}), \mathrm{d}(\mathrm{ApG}), \mathrm{d}(\mathrm{GpXpG})$ and interstrand crosslinks (50 52) preferentially by binding to the N7 residue of guanine. The cis form of platinum binds DNA and forms interstrand cross links much more avidly than the trans stereoisomer. Adduct formation distorts the helix structure of DNA (53). It has been hypothesized that these drug-mediated effects on DNA promote perturbations in cell cycle kinetics leading to apoptosis. Cell cycle analyses have demonstrated that apoptosis induced by platinum is initiated in G1 of the cell cycle and appears to require progression through the G1/S transition. Cells undergo apoptosis rather than progress through $\mathrm{S}$ phase (54-56).

Passage through a restriction point and entry into $\mathrm{S}$ phase is controlled by cyclin-dependent kinases (cdks) that are sequentially regulated by cyclins D, E, and A. In general, cdk activation requires cyclin binding. It depends on both positive and negative regulatory phosphorylations $(57,58)$ and can be constrained by at least two families of cdk inhibitory proteins $(59,60)$. As cells enter the cycle from quiescence (G0), one or more D-type cyclins (D1, D2, D3) are induced as part of the delayed early response to extracellular stimulation; both their synthesis and assembly with their catalytic partners, cdk4 and cdk6, depend on this external stimulation (61). As presented in our study, cisplatin treatment initiated the cellular cascade leading to cyclin D1 expression with associated re-entry into the cell cycle. This correlated with reduced levels of one of the known of endogenous inhibitors of cdk4 and cdk6, p16 $6^{\mathrm{INK} 4 \mathrm{a}}$ $(62,63)$. Currently, there are four known INK4 proteins $\left(\mathrm{p} 16^{\mathrm{INK} 4 \mathrm{a}}, \mathrm{p} 15^{\mathrm{INK} 4 \mathrm{~b}}, \mathrm{p} 18^{\mathrm{INK} 4 \mathrm{c}}, \mathrm{p} 19^{\mathrm{INK} 4 \mathrm{~d}}\right)$ which bind and inhibit cdk4 and cdk6 specifically. 


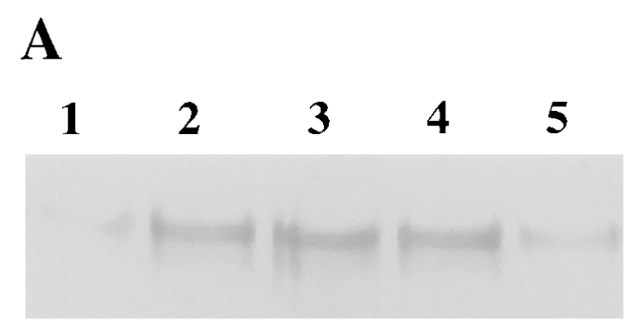

B
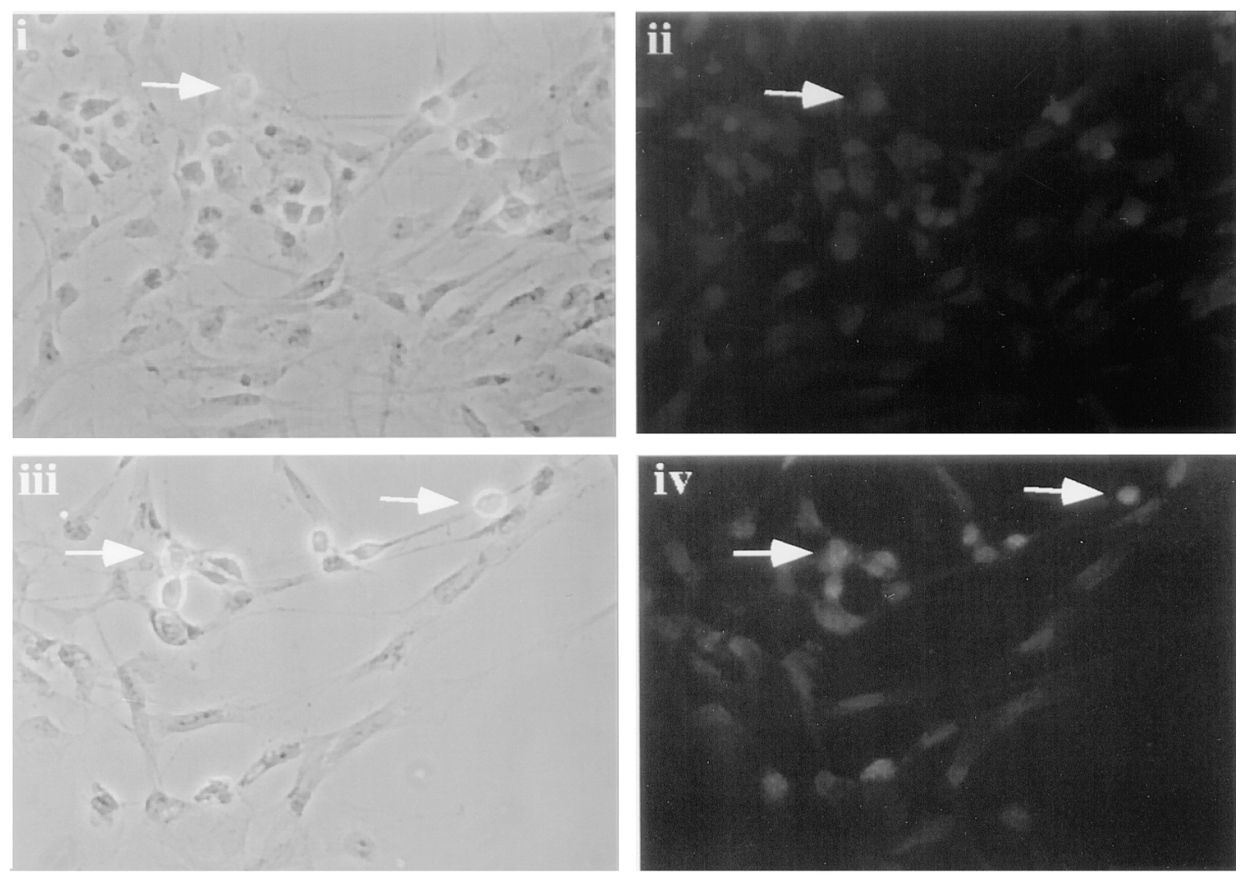

C

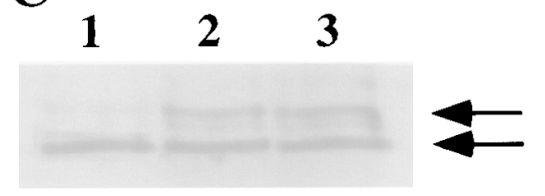

Figure 4. Cisplatin induces increased expression of cyclin D1 and hyperphosphorylation of $\mathrm{pRb}$ in DRG cultures. ( $A$ ) Neuron enriched DRG cultures were exposed to 3.5 $\mu \mathrm{g} / \mathrm{ml}$ cisplatin for 12 (lane 2) and $24 \mathrm{~h}$ (lane 3) in the presence of $5 \mathrm{ng} /$ $\mathrm{ml} \mathrm{NGF}$. Cisplatin treated $(24 \mathrm{~h})$ cultures were also exposed to $100 \mu \mathrm{M}$ of the caspase inhibitor z-VAD.fmk (lane 4) and $100 \mathrm{ng} / \mathrm{ml} \mathrm{NGF} \mathrm{(lane}$ 5 ). Cell lysates were separated by gel electrophoresis, immunoblotted with an anticyclin D1 monoclonal antibody and visualized by ECL. Western blot analysis revealed increased expression of cyclin D1 protein by $12 \mathrm{~h}$ in cisplatin treated compared to untreated cultures (lane 1 ). Cyclin D1 expression was similar in cisplatin treated cultures exposed to z-VAD.fmk as compared to those cultured in cisplatin alone. Reduced cyclin D1 protein expression was observed in cisplatin treated cultures grown in the presence of 100 ng/ml NGF. (B) Immunofluorescence microscopy of cisplatin treated DRG cultures $(i v ; 3.5 \mu \mathrm{g} / \mathrm{ml}$ for $24 \mathrm{~h}$ ) demonstrated that the increased expression of cyclin D1 occurred primarily in neurons ( $a r$ rows), as observed by phase contrast microscopy (iii). Immunohistochemical assays were performed before appreciable cell death associated with cisplatin treated cultures was observed. Measurable cell death begins at 24 to $48 \mathrm{~h}$. Cyclin D1 staining was not observed in untreated cultures ( $i$ and $i i$, magnification of 100). (C) Neuronal cultures were exposed to $3.5 \mu \mathrm{g} / \mathrm{ml}$ cisplatin (lane 2) plus $100 \mu \mathrm{M} \mathrm{z}$-VAD.fmk (lane 3) for $24 \mathrm{~h}$. Proteins $(200 \mu \mathrm{g} /$ sample) from cell lysates were electrophoretically separated and immunoblotted with a monoclonal an-

tibody to $\mathrm{pRb}$. The hypophosphorylated form of $\mathrm{pRb}(110 \mathrm{kD}$, lower arrow) was distinguishable from hyperphosphorylated $\mathrm{pRb}$ (upper arrow) which has an apparent molecular weight of $116 \mathrm{kD}$. Proteins from untreated cultures expressed low levels of the hyperphosphorylated form of $\mathrm{pRb}$ (lane 1). All cultures were grown in the presence of $5 \mathrm{ng} / \mathrm{ml}$ NGF.

The molecular mechanisms involved in cell cycle checkpoints are becoming more clearly defined. The tumor suppressor proteins $\mathrm{p} 53$ and $\mathrm{pRb}$ play critical roles in both cell cycle arrest and apoptosis. p53 links DNA damage to the regulation of $\mathrm{G} 1 / \mathrm{S}$ checkpoint control. pRb is a nuclear protein with at least five different phosphorylated forms in cycling cells (6466). The relative balance among these forms varies during the four phases of the cell cycle $(67,68)$. Upstream regulation of $\mathrm{pRb}$ involves interaction with the cyclins. Physical and functional interactions involving cyclin D1 and hypophosphorylated forms of $\mathrm{pRb}$ have been demonstrated recently both in vitro and in vivo (69-71). This is consistent with reports show- ing that loss of $\mathrm{pRb}$ increases the susceptibility of cells to undergo apoptotic cell death (72-75). This suggests that $\mathrm{pRb}$ and cyclin D1 may function as antagonists of each other. If $\mathrm{pRb}$ regulates cyclin D1 activity, it can be proposed that hypophosphorylated forms of $\mathrm{pRb}$ decrease during apoptosis while cyclin D1 increases. Findings from our study would support this hypothesis as hyperphosphorylated forms of $\mathrm{pRb}$ were observed in cisplatin-treated neuronal cultures at time points preceding morphological changes associated with cell death and commensurate with increases in cyclin D1 protein.

One of the major conclusions from this study is, therefore, that cisplatin may cause cell death in neurons by inducing re- 
A

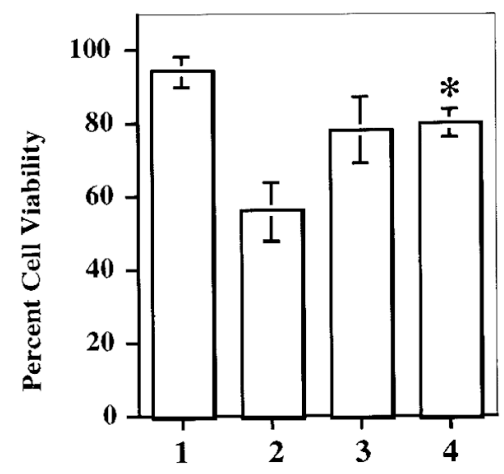

C

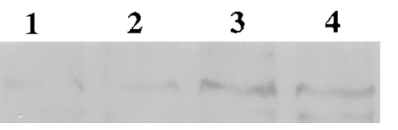

Figure 5. NGF protects DRG cultures against cisplatin-induced apoptosis. (A) DRG cultures were used to quantify the protective effect of NGF against cisplatin $(3.5 \mu \mathrm{g} / \mathrm{ml})$ neurotoxicity. Neurons were treated with cisplatin for $48 \mathrm{~h}$ in the presence of 5 (2), 50 (3), and $100 \mathrm{ng} / \mathrm{ml} \mathrm{NGF}$ (4). Addition of 50 and $100 \mathrm{ng} / \mathrm{ml} \mathrm{NGF}$ increased neuronal viability compared to cultures exposed to $5 \mathrm{ng} / \mathrm{ml} \mathrm{NGF}$. The number of viable neurons after $48 \mathrm{~h}$ of cisplatin treatment was significantly increased in the presence of $100 \mathrm{ng} / \mathrm{ml}$ NGF compared to cisplatin-treated neurons cultured in $5 \mathrm{ng} / \mathrm{ml} \mathrm{NGF}(* P<0.01$ Student's $t$ test). Cell viability from untreated cultures was also quantified (1).

$(B)$ Protection by NGF was also observed by a reduction in DNA laddering. DNA was harvested from cultures described above, separated by gel electrophoresis, and visualized by ethidium bromide. Cisplatintreated cultures in the presence of 5 (lane 2) and 50 (lane 3) ng/ml NGF revealed DNA fragmentation. DNA laddering was significantly reduced in cultures exposed to cisplatin plus $100 \mathrm{ng} / \mathrm{ml} \mathrm{NGF}$ (lane 4). Untreated cultures did not reveal any internucleosomal fragmentation (lane 1). (C) Neuron-enriched DRG cultures were exposed to $100 \mathrm{ng} / \mathrm{ml}$ NGF for 3 (lane 2), 6 (lane 3), and $12 \mathrm{~h}$ (lane 4). Proteins $(100 \mu \mathrm{g} / \mathrm{sample})$ from cell lysates were separated by gel electrophoresis and immunoblotted with a monoclonal antibody to p16 ${ }^{\mathrm{INK} 4 \mathrm{a}}$. ECL detection revealed increased expression of $\mathrm{p} 16^{\mathrm{INK} 4 \mathrm{a}}$ protein with NGF exposure, peaking at $6 \mathrm{~h}$ treatment. This indicated that NGF was promoting the expression of G1-dependent cell cycle inhibitory elements. Cell lysates from neurons exposed to control levels of NGF (5 $\mathrm{ng} / \mathrm{ml}$ ) were separated in lane 1 .

entry into the cell cycle. There is evidence from other systems that disturbances in cell cycle regulation may lead to cell death in postmitotic neurons (76-80). In attempting to clarify the association of unscheduled cell division and cell death in the nervous system, many of these studies used transformed and proliferation-competent cells which are not necessarily directly applicable to the postmitotic neuron. In using primary DRG neuronal cultures, our study allowed us to directly examine the role of cell cycle regulatory elements in cisplatin-induced neurotoxicity. Our observations of cisplatin-mediated cyclin D1 expression, $\mathrm{pRb}$ hyperphosphorylation and neuroprotection conferred by NGF are in accordance with a recent report characterizing the role of cyclin-dependent kinase inhibitors and dominant negative cdk4 and cdk6 in promoting neuronal sur-
A

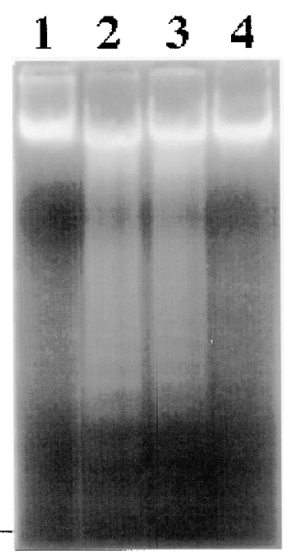

B
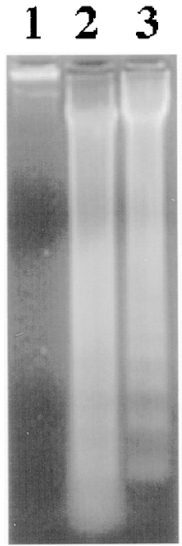

C

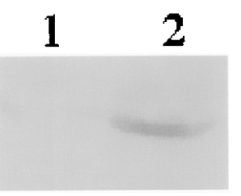

D

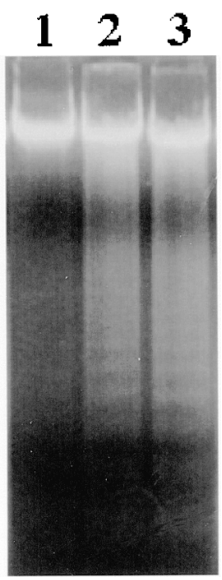

Figure 6. NGF only protects cells expressing gp140 ${ }^{\text {TrkA }}$. (A) PC12 cells were exposed to cisplatin $(3.5 \mu \mathrm{g} / \mathrm{ml}$ for $24 \mathrm{~h}$ ) alone (lane 2$)$ or with the addition of 5 (lane 3 ) or 100 (lane 4 ) ng/ml NGF. (B) The human colon cancer cell line HT-29 was also exposed to cisplatin alone (lane 2) or with the addition of $100 \mathrm{ng} / \mathrm{ml} \mathrm{NGF}$ (lane 3). DNA was harvested, separated, and visualized as described above. In both cell lines, DNA fragmentation was observed with cisplatin treatment which was reduced with $100 \mathrm{ng} / \mathrm{ml}$ NGF exposure in PC12 cells but not in the HT-29 cell line. DNA from untreated cells in both cell lines was separated in lane 1. (C) Western blot analysis of untreated PC12 and HT-29 cells demonstrated expression of gp140 ${ }^{\text {TrkA }}$ protein in PC12 cells (lane 2) but not in the HT-29 cell line (lane 1). ECL detection was overexposed to demonstrate absence of gp140 TrkA in HT-29. (D) NGF-dependent postmitotic PC12 cells were exposed to cisplatin $(3.5 \mu \mathrm{g} / \mathrm{ml}$ for $48 \mathrm{~h}$; lane 2) or with the addition of $100 \mathrm{ng} / \mathrm{ml} \mathrm{NGF}$ plus $200 \mu \mathrm{M}$ of the gp140 ${ }^{\text {TrkA }}$ tyrosine kinase inhibitor K252a (lane 3 ). Protection against DNA fragmentation was abrogated in cells exposed to high levels of NGF plus K252a. This demonstrates that the neuroprotective potential conferred by NGF in cisplatin-treated PC12 cells (as shown in $A$ ) is probably mediated through activation of the TrkA receptor.

vival under neurotrophic deprivation (81). While our collective studies suggest a role of cyclin expression and cdk activation in both cisplatin and growth factor deprivation models of neuronal apoptosis, it remains to be determined if expression 
and activation of cell cycle elements is a necessary component associated with other forms of neuronal death.

The mechanistic studies presented here may have important therapeutic implications. Results from this study suggest that disruption in cell cycle regulation is a possible mechanism for cisplatin-induced neurotoxicity. Studies are now underway to characterize changes in these cell cycle elements in cancer cells exposed to cisplatin. If platinum compounds kill cancer cells and neurons by similar mechanisms, protective strategies need to restrict access of the drug to the nervous system or use neuron-specific protective strategies. Recently, a number of second generation platinum analogs have been evaluated in the search for a platinum compound with comparable or superior antitumor activity and reduced toxicity (52). In animal models (82) and tissue culture (83), the relative reduction in neurotoxicity appears to parallel a reduction in chemotherapeutic efficacy; as higher doses are used, neurotoxicity of carboplatin is becoming apparent. The concordance of the animal and tissue culture studies with the clinical deficits and autopsy studies demonstrate that this is a valid model system for cisplatin neurotoxicity.

This is the first demonstration that cisplatin induces apoptosis in sensory neurons which is prevented by NGF. Future studies will involve dissection of the signal transduction pathways by which NGF is exerting its protective effect. It will also be very important to understand why cisplatin-DNA adducts induce cell cycle perturbations. It is probable that this will be a critical step for our understanding of both the chemotherapeutic and neurotoxic actions of platinum compounds.

\section{Acknowledgments}

The secretarial assistance of Ms. Linda A. Goldbeck was greatly appreciated.

\section{References}

1. Von Hoff, D.D., R. Schilsky, C.M. Reichert, R.L. Reddick, M. Rozencweig, R.C. Young, and F.M. Muggia. 1979. Toxic effects of cis-dichlorodiammineplatinum(II) in man. Cancer Treat. Rep. 63:1527-1531.

2. Mollman, J.E. 1990. Cisplatin neurotoxicity. N. Engl. J. Med. 322:126-127.

3. Walsh, T.J., A.W. Clark, I.M. Parhad, and W.R. Green. 1982. Neurotoxic effects of cisplatin therapy. Arch. Neurol. 39:719-720.

4. Calabresi, P., and B.A. Chabner. 1996. Chemotherapy of neoplastic diseases. In Goodman \& Gilman's The Pharmacological Basis of Therapeutics. Hardman, J.G., L.E. Limbird, P.B. Molinoff, R.W. Ruddon, and A.G. Gilman, editors. McGraw-Hill, New York. 1225-1287.

5. Gregg, R.W., J.M. Molepo, V.J.A. Monpetit, N.Z. Mikael, D. Redmond, M. Gadia, and D.J. Stewart. 1992. Cisplatin neurotoxicity: the relationship between dosage, time, and platinum concentration in neurologic tissues, and morphologic evidence of toxicity. J. Clin. Oncol. 10:795-803.

6. Krarup-Hansen, A., K. Fugleholm, S. Helweg-Larsen, E.N. Hauge, H. Schmalbruch, W. Trojaborg, and C. Krarup. 1993. Examination of distal involvement in cisplatin-induced neuropathy in man. An electrophysiological and histological study with particular reference to touch receptor function. Brain. 116:1017-1041.

7. Fu, K.K., E.F.Y. Kai, and C.K. Leung. 1995. Cisplatin neuropathy: a prospective clinical and electrophysiological study in Chinese patients with ovarian carcinoma. J. Clin. Pharm. Ther. 20:167-172.

8. McKeage, M.J. 1995. Comparative adverse effect profiles of platinum drugs. Drug Saf. 13:228-244.

9. Ozols, R.F., Y. Ostchega, C.E. Myers, and R.C. Young. 1985. High-dose cisplatin in hypertonic saline in refractory ovarian cancer. J. Clin. Oncol. 3: $1246-1250$.

10. Thompson, S.W., L.E. Davis, M. Kornfeld, R.D. Hilgers, and J.C. Standefer. 1984. Cisplatin neuropathy. Clinical, electrophysiologic, morphologic, and toxicologic studies. Cancer. 54:1269-1275.

11. Roelofs, R.I., W. Hrushesky, J. Rogin, and L. Rosenberg. 1984. Peripheral sensory neuropathy and cisplatin chemotherapy. Neurology. 34:934-938.
12. Grunberg, S.M., S. Sonka, L.L. Stevenson, and F.M. Muggia. 1989. Progressive paresthesias after cessation of therapy with very high-dose cisplatin. Cancer Chemother. Pharmacol. 25:62-64.

13. Mollman, J.E., W.M. Hogan, D.J. Glover, and L.F. McCluskey. 1988. Unusual presentation of cis-platinum neuropathy. Neurology. 38:488-490.

14. Machover, D., E. Diaz-Rubio, A. De Gramont, A. Schilf, J.-J. Gastiaburu, S. Brienza, M. Itzhaki, G. Metzger, D. N'Daw, J. Vignoud, et al. 1996. Two consecutive phase II studies of oxaliplatin (L-OHP) for treatment of patients with advanced colorectal carcinoma who were resistant to previous treatment with fluoropyrimidines. Ann. Oncol. 7:95-98.

15. Lévi, F., R. Zidani, J.-L. Misset, and the International Organization for Cancer Chronotherapy. 1997. Randomised multicentre trial of chronotherapy with oxaliplatin, fluorouracil, and folinic acid in metastatic colorectal cancer. Lancet. 350:681-686.

16. Siddiqui, N., A.V. Boddy, H.D. Thomas, N.P. Bailey, L. Robson, M.J. Lind, and A.H. Calvert. 1997. A clinical and pharmacokinetic study of the combination of carboplatin and paclitaxel for epithelial ovarian cancer. Br. J. Cancer. 75:287-294.

17. Cowan, J.D., M.S. Kies, J.L. Roth, and R.P. Joyce. 1980. Nerve conduction studies in patients treated with cis-diamminedichloroplatinum(II): a preliminary report. Cancer Treat. Rep. 64:1119-1122.

18. Cavaletti, G., G. Bogliun, L. Marzorati, G. Tredici, N. Colombo, G. Parma, and M.D. Miceli. 1994. Long-term peripheral neurotoxicity of cisplatin in patients with successfully treated epithelial ovarian cancer. Anticancer Res. 14:1287-1292.

19. Apfel, S.C., J.C. Arezzo, L. Lipson, and J.A. Kessler. 1992. Nerve growth factor prevents experimental cisplatin neuropathy. Ann. Neurol. 31:76-80.

20. Hamers, F.P.T., J.H. Brakkee, E. Cavalletti, M. Tedeschi, L. Marmonti, G. Pezzoni, J.P. Neijt, and W.H. Gispen. 1993. Reduced glutathione protects against cisplatin-induced neurotoxicity in rats. Cancer Res. 53:544-549.

21. Cavaletti, G., C. Minoia, M. Schieppati, and G. Tredici. 1994. Protective effects of glutathione on cisplatin neurotoxicity in rats. Int. J. Radiat. Oncol. Biol. Phys. 29:771-776.

22. Gerritsen van der Hoop, R., F.P.T. Hamers, J.P. Neijt, H. Veldman, W.H. Gispen, and F.G.I. Jennekens. 1994. Protection against cisplatin induced neurotoxicity by ORG 2766: histological and electrophysiological evidence. $J$. Neurol. Sci. 126:109-115.

23. Lorenzo, N.Y., W.S. Brimijoin, and A.J. Windebank. 1994. Cisplatininduced in vivo neurophysiological changes and its prevention by $\mathrm{ACTH}_{4-9}$ Ann. Neurol. 36:284a. (Abstr.)

24. Cece, R., M.G. Petruccioli, G. Cavaletti, I. Barajon, and G. Tredici. 1995. An ultrastructural study of neuronal changes in dorsal root ganglia (DRG) of rats after chronic cisplatin administrations. Histol. Histopathol. 10: 837-845.

25. Tomiwa, K., C. Nolan, and J.B. Cavanagh. 1986. The effects of cisplatin on rat spinal ganglia: a study by light and electron microscopy and by morphometry. Acta Neuropathol. (Berl.). 69:295-308.

26. Cavaletti, G., G. Tredici, P. Marmiroli, D. Fabbrica, and M. Braga. 1994. Off-treatment course of cisplatin-induced dorsal root ganglia neuronopathy in rats. In Vivo. 8:313-316.

27. Barajon, I., M. Bersani, M. Quartu, M. Del Fiacco, G. Cavaletti, J.J. Holst, and G. Tredici. 1996. Neuropeptides and morphological changes in cisplatin-induced dorsal root ganglion neuronopathy. Exp. Neurol. 138:93-104.

28. Hayakawa, K., G. Sobue, T. Itoh, and T. Mitsuma. 1994. Nerve growth factor prevents neurotoxic effects of cisplatin, vincristine and taxol, on adult rat sympathetic ganglion explants in vitro. Life Sci. 55:519-525.

29. Konings, P.N.M., W.K. Makkink, A.M.L. van Delft, and G.S.F. Ruigt 1994. Reversal by NGF of cytostatic drug-induced reduction of neurite outgrowth in rat dorsal root ganglia in vitro. Brain Res. 640:195-204.

30. Windebank, A.J., A.G. Smith, and J.W. Russell. 1994. The effect of nerve growth factor, ciliary neurotrophic factor, and ACTH analogs on cisplatin neurotoxicity in vitro. Neurology. 44:488-494.

31. Boekelheide, K., M.E. Arcila, and J. Eveleth. 1992. cis-Diamminedichloroplatinum (II) (cisplatin) alters microtubule assembly dynamics Toxicol. Appl. Pharmacol. 116:146-151.

32. Russell, J.W., A.J. Windebank, M.A. McNiven, D.J. Brat, and W.S. Brimijoin. 1995. Effect of cisplatin and $\mathrm{ACTH}_{4-9}$ on neural transport in cisplatininduced neurotoxicity. Brain Res. 676:258-267.

33. Tredici, G., G. Cavaletti, M.G. Petruccioli, D. Fabbrica, M. Tedeschi, and P. Venturino. 1994. Low-dose glutathione administration in the prevention of cisplatin-induced peripheral neuropathy in rats. Neurotoxicology. 15:701-704.

34. Cascinu, S., L. Cordella, E. Del Ferro, M. Fronzoni, and G. Catalano. 1995. Neuroprotective effect of reduced glutathione on cisplatin-based chemotherapy in advanced gastric cancer: a randomized double-blind placebo-controlled trial. J. Clin. Oncol. 13:26-32.

35. Treskes, M., and W.J.F. van der Vijgh. 1993. WR2721 as a modulator of cisplatin- and carboplatin-induced side effects in comparison with other chemoprotective agents: a molecular approach. Cancer Chemother. Pharmacol. 33:93106.

36. Capizzi, R.L. 1994. Protection of normal tissues from the cytotoxic effects of chemotherapy by amifostine (Ethyol): clinical experiences. Semin. Oncol. $21: 8-15$ 
37. Gispen, W.H., F.P.T. Hamers, C.J. Vecht, F.G.I. Jennekens, and J.P. Neyt. 1992. ACTH/MSH like peptides in the treatment of cisplatin neuropathy. J. Steroid Biochem. Mol. Biol. 43:179-183.

38. Hol, E.M., W.H. Gispen, and P.R. Bär. 1995. ACTH-related peptides: receptors and signal transduction systems involved in their neurotrophic and neuroprotective actions. Peptides. 16:979-993.

39. Malgrange, B., P. Delrée, J.M. Rigo, H. Baron, and G. Moonen. 1994. Image analysis of neuritic regeneration by adult rat dorsal root ganglion neurons in culture: quantification of the neurotoxicity of anticancer agents and of its prevention by nerve growth factor or basic fibroblast growth factor but not brain-derived neurotrophic factor or neurotrophin-3. J. Neurosci. Methods. 53: 111-122.

40. Gao, W.-Q., N. Dybdal, N. Shinsky, A. Murnane, C. Schmelzer, M. Siegel, G. Keller, F. Hefti, H.S. Phillips, and J.W. Winslow. 1995. Neurotrophin-3 reverses experimental cisplatin-induced peripheral sensory neuropathy. Ann. Neurol. 38:30-37.

41. Schmidt, Y., J.W. Unger, I. Bartke, and R. Reiter. 1995. Effect of nerve growth factor on peptide neurons in dorsal root ganglia after taxol or cisplatin treatment and in diabetic (db/db) mice. Exp. Neurol. 132:16-23.

42. Zheng, J.L., R.R. Stewart, and W.Q. Gao. 1995. Neurotrophin-4/5 enhances survival of cultured spiral ganglion neurons and protects them from cisplatin neurotoxicity. J. Neurosci. 15:5079-5087.

43. Zheng, J.L., R.R. Stewart, and W.-Q. Gao. 1995. Neurotrophin-4/5, brain-derived neurotrophic factor, and neurotrophin-3 promote survival of cultured vestibular ganglion neurons and protect them against neurotoxicity of ototoxins. J. Neurobiol. 28:330-340.

44. Windebank, A.J., and J.F. Poduslo. 1986. Neuronal growth factors produced by adult peripheral nerve after injury. Brain Res. 385:197-200.

45. Batistatou, A., and L.A. Greene. 1993. Internucleosomal DNA cleavage and neuronal cell survival/death. J. Cell Biol. 122:523-532.

46. Lucidi-Phillipi, C.A., D.O. Clary, L.F. Reichardt, and F.H. Gage. 1996. TrkA activation is sufficient to rescue axotomized cholinergic neurons. Neuron. 16:653-663.

47. Gill, J.S., D.C. Connolly, M.J. McManus, N.J. Maihle, and A.J. Windebank. 1996. Suramin induces phosphorylation of the high-affinity nerve growth factor receptor in PC12 cells and dorsal root ganglion neurons. J. Neurochem. 66:963-972.

48. Nicholson, D.W., A. Ali, N.A. Thornberry, J.P. Vaillancourt, C.K. Ding, M. Gallant, Y. Gareau, P.R. Griffin, M. Labelle, Y.A. Lazebnik, et al. 1995. Identification and inhibition of the ICE/CED-3 protease necessary for mammalian apoptosis. Nature. 376:37-43.

49. Jayadev, S., B. Liu, A.E. Bielawska, J.Y. Lee, F. Nazaire, M.Y. Pushkareva, L.M. Obeid, and Y.A. Hannun. 1995. Role for ceramide in cell cycle arrest. J. Biol. Chem. 270:2047-2052.

50. Reed, E., M. Poirier, R.C. Young, and R.F. Ozols. 1988. High dose cisplatin with hypertonic saline: toxicity and therapeutic results. In Organ Directed Toxicities of Anti-Cancer Drugs. Hacher, M.P., J.S. Lazo, and T.R. Tritton, editors. Matinous Nighoff, Boston. 203-213.

51. Reed, E., S. Sauerhoff, and M.C. Poirier. 1988. Quantitation of platinum-DNA binding after therapeutic levels of drug exposure. A novel use of graphite furnace spectrometry. Atom. Spectro. 9:93-95.

52. Reed, E., and K.W. Kohn. 1990. Platinum analogues. In Cancer Chemotherapy: Principles and Practice. Chabner, B.A. and J.M. Collins, editors. J.B. Lippincott Co., Philadelphia. 465-490.

53. Huang, H., L. Zhu, B.R. Reid, G.P. Drobny, and P.B. Hopkins. 1995. Solution structure of a cisplatin-induced DNA interstrand cross-link. Science. 270:1842-1845.

54. Powell, S.N., and E.H. Abraham. 1993. The biology of radioresistance: similarities, differences and interactions with drug resistance. Cytotechnology. $12: 325-345$.

55. Allday, M.J., G.J. Inman, D.H. Crawford, and P.J. Farrell. 1995. DNA damage in human $B$ cells can induce apoptosis, proceeding from $\mathrm{G}_{1} / \mathrm{S}$ when $\mathrm{p} 53$ is transactivation competent and $\mathrm{G}_{2} / \mathrm{M}$ when it is transactivation defective. EMBO J. 14:4994-5005.

56. Enoch, T., and C. Norbury. 1995. Cellular responses to DNA damage: cell-cycle checkpoints, apoptosis and the roles of p53 and ATM. Trends Biochem. Sci. 20:426-430.

57. Weinstein, I.B. 1996. Relevance of cyclin D1 and other molecular markers to cancer chemoprevention. J. Cell. Biochem. Suppl. 25:23-28.

58. Fisher, R.P. 1997. CDKs and cyclins in transition(s). Curr. Opin. Genet. Dev. 7:32-38.

59. Elledge, S.J., and J.W. Harper. 1994. Cdk inhibitors: on the threshold of checkpoints and development. Curr. Opin. Cell Biol. 6:847-852.

60. Sherr, C.J., and J.M. Roberts. 1995. Inhibitors of mammalian $\mathrm{G}_{1}$ cyclindependent kinases. Genes Dev. 9:1149-1163.

61. Sherr, C.J. 1995. D-type cyclins. Trends Biochem. Sci. 20:187-190.

62. Hengst, L., V. Dulic, J.M. Slingerland, E. Lees, and S.I. Reed. 1994. A cell cycle-regulated inhibitor of cyclin-dependent kinases. Proc. Natl. Acad. Sci. USA. 91:5291-5295.

63. Nobori, T., K. Miura, D.J. Wu, A. Lois, K. Takabayashi, and D.A. Carson. 1994. Deletions of the cyclin-dependent kinase-4 inhibitor gene in multiple human cancers. Nature. 368:753-756.

64. De Luca, A., V. Esposito, A. Baldi, and A. Giordano. 1996. The retinoblastoma gene family and its role in proliferation, differentiation and development. Histol. Histopathol. 11:1029-1034.

65. Giordano, A., and H.E. Kaiser. 1996. The retinoblastoma gene: its role in cell cycle and cancer. In Vivo. 10:223-227.

66. Sidle, A., C. Palaty, P. Dirks, O. Wiggan, M. Kiess, R.M. Gill, A.K. Wong, and P.A. Hamel. 1996. Activity of the retinoblastoma family proteins, pRB, p107, and p130, during cellular proliferation and differentiation. Crit. Rev. Biochem. Mol. Biol. 31:237-271.

67. Lees, J.A., K.J. Buchkovich, D.R. Marshak, C.W. Anderson, and E. Harlow. 1991. The retinoblastoma protein is phosphorylated on multiple sites by human cdc2. EMBO J. 10:4279-4290.

68. DeCaprio, J.A., Y. Furukawa, F. Ajchenbaum, J.D. Griffin, and D.M Livingston. 1992. The retinoblastoma-susceptibility gene product becomes phosphorylated in multiple stages during cell cycle entry and progression. Proc Natl. Acad. Sci. USA. 89:1795-1798.

69. Hatakeyama, M., R.A. Herrera, T. Makela, S.F. Dowdy, T. Jacks, and R.A. Weinberg. 1994. The cancer cell and the cell cycle clock. Cold Spring Harbor Symp. Quant. Biol. 59:1-10.

70. Hinds, P.W., S.F. Dowdy, E.N. Eaton, A. Arnold, and R.A. Weinberg. 1994. Function of a human cyclin gene as an oncogene. Proc. Natl. Acad. Sci. USA. 91:709-713.

71. Dowdy, S.F., P.W. Hinds, K. Louie, S.I. Reed, A. Arnold, and R.A Weinberg. 1993. Physical interaction of the retinoblastoma protein with human D cyclins. Cell. 73:499-511.

72. Motokura, T., and A. Arnold. 1993. Cyclin D and oncogenesis. Curr. Opin. Genet. Dev. 3:5-10.

73. Lee, E.Y.-H.P., N. Hu, S.-S.F. Yuan, L.A. Cox, A. Bradley, W.-H. Lee, and K. Herrup. 1994. Dual roles of the retinoblastoma protein in cell cycle regulation and neuron differentiation. Genes Dev. 8:2008-2021.

74. Almasan, A., Y. Yin, R.E. Kelly, E.Y.-H.P. Lee, A. Bradley, W. Li, J.R. Bertino, and G.M. Wahl. 1995. Deficiency of retinoblastoma protein leads to inappropriate S-phase entry, activation of E2F-responsive genes, and apoptosis. Proc. Natl. Acad. Sci. USA. 92:5436-5440.

75. Almasan, A., S.P. Linke, T.G. Paulson, L.-C. Huang, and G.M. Wahl 1995. Genetic instability as a consequence of inappropriate entry into and progression through S-phase. Cancer Metastasis Rev. 14:59-73.

76. Freeman, R.S., S. Estus, and E.M. Johnson, Jr. 1994. Analysis of cell cycle-related gene expression in postmitotic neurons: selective induction of Cyclin D1 during programmed cell death. Neuron. 12:343-355.

77. Ferrari, G., C.Y.I. Yan, and L.A. Greene. 1995. N-acetylcysteine (Dand L-stereoisomers) prevents apoptotic death of neuronal cells. J. Neurosci. 15:2857-2866

78. Farinelli, S.E., and L.A. Greene. 1996. Cell cycle blockers mimosine, ciclopirox, and deferoxamine prevent the death of PC12 cells and postmitotic sympathetic neurons after removal of trophic support. J. Neurosci. 16:11501162

79. Kranenburg, O., A.J. van der Eb, and A. Zantema. 1996. Cyclin D1 is an essential mediator of apoptotic neuronal cell death. EMBO J. 15:46-54

80. Park, D.S., S.E. Farinelli, and L.A. Greene. 1996. Inhibitors of cyclindependent kinases promote survival of post-mitotic neuronally differentiated PC12 cells and sympathetic neurons. J. Biol. Chem. 271:8161-8169.

81. Park, D.S., B. Levine, G. Ferrari, and L.A. Greene. 1997. Cyclin dependent kinase inhibitors and dominant negative cyclin dependent kinase 4 and 6 promote survival of NGF-deprived sympathetic neurons. J. Neurosci. 17:89758983

82. Cavaletti, G., D. Fabbrica, O. De Negri, C. Minoia, L. Frattola, and G Tredici. 1998. A model of chronic administration of carboplatin to evaluate its effect on the peripheral nervous system of the rat. Toxicol. Appl. Pharmacol. In press.

83. Baslo, M.B., J.S. Gill, and A.J. Windebank. 1997. Rapid prediction of potential neurotoxicity of novel cisplatin analogs. Neurology. 48:319a. (Abstr.) 